\title{
WORKSHOP AS A METHOD OF TRAINING FUTURE EXPERTS IN TECHOGENIC AND ENVIRONMENTAL SAFETY
}

\author{
N. Bordiug, A. Rashchenko, T. Les
}

Стаття містить результати наукових досліджень у сфері застосування workshop у навчанні майбутніх фахівиів з техногенної та екологічної безпеки. Доведено актуальність методу у контексті підготовки компетентних та конкурентоспроможних на ринку праці Украӥни спеціалістів. У результаті дослідження виокремлено та охарактеризовано основні складові workshop як методу практичноорієнтованого навчання фахівців. Встановлено, щзо процес створення workshop з теми «Моніторинг надзвичайних ситуацій» має складатись з трьох підсистем: підготовчо-иільової, організаційно - методичної, аналітично - прогностичної. Наведено його основні методичні складові.

Розроблено workshop з теми «Моніторинг надзвичайних ситуацій» для майбутніх фахівців зі спеціальності 183 «Технології захисту навколишнього середовища». Метою якого є створення системи моніторингу надзвичайної ситуачії на прикладі певного об'єкта та розробка можливих сценарїв запобігання, попередження та ліквідації наслідків аварії. Доведено, щз метод workshop забезпечить можливість застосування студентами попередньо набутих знань, вмінь і навичок з моніторингу навколишнього природного середовища та екологічної безпеки. Крім того, такий метод забезпечить аналізу студентами можливих сценаріїв виникнення небезпечних ситуаџій на території певного регіону, створення ними системи кризового моніторингу за станом складових довкілля та розробки практичних рекомендацій щодо иляхів ліквідації аварії та ї̈ попередження у майбутньому. Визначено, щьо у ході проведення workshop, запрошені стейкхолдери мають можливість підібрати собі працівників. Доведено, щзо навчання фахівців з техногенно-екологічної безпеки з використанням workshop забезпечує формування компетентних та конкурентоспроможних працівників, готових працฺювати на конкретних вітчизняних роботодавців, кейси яких було опрацьовано під час занять, щзо в подальшому зупинить відтік фахівців з України

Ключові слова: workshop, інновачійні методи навчання, освітній процес, фахівців з техногенноекологічної безпека

Copyright (C) 2020, N. Bordiug, A. Rashchenko. This is an open access article under the CC BY license (http://creativecommons.org/licenses/by/4.0).

\section{Introduction}

Year after year the world ecological crisis is growing, and training environmental experts, especially technogenic and environmental safety engineers, who are able to respond quickly to changes in the environment, are relevant. Therefore, one of the components of the system of training these specialists is fundamental, professional and practical training that will provide not only the personal development of a student, but also the formation of professional competence components: engineering and production, analytical, environmental, scientific and other ones.

This problem is especially urgent in the context of intensification of labor migration processes, observed in Ukraine and in the world as a whole. After all, in order to occupy the positions of specialists in ecological and technogenic safety in the domestic labor market, they have to meet specific, sometimes quite high professional requirements. Obviously, in order to stop the process of labor migration, that is now an integral part of Ukrainian society, young people must be provided with decent jobs and wages.

Therefore, it is important that the specialists, remaining in the country, are sufficiently competent and competitive.
The content and modern training methods, used in the educational process, play a significant role in the formation of the professional competence of future technogenic and environmental safety specialists. Therefore, it is relevant to study modern innovative teaching methods to ensure the quality of specialists training in times of demographic crisis and high market competition in Ukraine.

\section{Literary review}

Researchers emphasize that there is a gap between the technologies, available to students in everyday life, and those technological techniques and decisions that are used in the educational process $[1,2]$. Given that the latest teaching methods and techniques are able to make the process of knowledge acquisition more qualitative and attractive to students, the need for their application is beyond doubt [3]. Therefore, teachers and mentors should encourage students, through the use of innovative technologies in teaching, to gain knowledge and implement practical skills in the professional field $[1,4]$.

The interactive technologies are widely used in training experts in technogenic and environmental safety. They ensure the creation of learning environments, in which students interact actively and everyone can feel 
him/herself successful [5]. One of these methods is the workshop, as it is a particular system of action of a teacher, student and employer, aimed at an effective solution of educational tasks, including the development of knowledge and environmental monitoring skills. In the process of analyzing the scientific works on the use of interactive teaching methods, we have found a small number of works, devoted to conducting the workshops and describing the methodology of their setting up, although a methodological guideline for the use in postgraduate pedagogical education has been developed [6].

Some scholars [7] consider workshops to be part of dynamic learning that takes place with the direct activity of the participants themselves. They are actively involved in the work and are responsible for their educational process. The workshop has been studied as a tool for practice-oriented learning [8].

In order to provide qualitative training for future technogenic and environmental safety experts, it is proposed to use one of the innovative, practice- oriented teaching methods - the workshop [9]. This method assumes that during the session participants acquire new knowledge and practical skills through personal activity, with the theoretical unit of study, taking a minimum time. Students learn independently and actively interact with all participants of the educational event. The introduction of the workshop into the educational process contributes to the fulfillment of a number of tasks: using modern innovative technologies in teaching; increasing the level of motivation for the process of education, professional training and professional activity; the possibility to realize ideas and projects, creating new products in the professional sphere and their practical implementation [10].

The workshop is characterized by the integrity of learning, activity of participants, independent decision making, self-expression, teamwork [10].

Therefore, the sufficient justification of the effectiveness of the workshop as an innovative training event, where participants gain knowledge through the high intensity of group interaction as well as activity and independence of participants, current and personal experience, allows us to offer the created training workshop on the example of the topic "Monitoring Emergency Situations". The aim of the last is to form the proper professional competences and competitiveness of future technogenic and environmental safety specialists in the labor market of Ukraine.

\section{The aim and objectives of the study}

The purpose of the study is to determine the organizational and practical aspects of the implementation of the workshop in the educational process during the professional training of technogenic and environmental safety experts.

The following tasks have been set to achieve this goal:

1) to identify and characterize the main components of the workshop as a method of practice- oriented training of specialists;

2) to develop the workshop on the topic "Emergency Monitoring" for future specialists in specialty 183 "Environmental Technologies".

\section{The main methodological components of the} workshop

The result of the workshop is to solve a detail, complex problem; the duration of the workshop may be different. We have determined that the best time makes two hours of study, but the number of lessons on one topic can be from one to five. To organize a quality workshop, it is necessary to use various methods that will contribute to students' interaction, namely discussions, business games, trainings, brainstorming and more.

Setting up of the workshop on the topic "Emergency Monitoring" has three subsystems:

The first is the preparatory-target subsystem: the purpose and objectives of the workshop; identifying practical skills to be developed; the scheme of carrying out; analysis of literary and regulatory sources on the subject, including the use of international and national information sources.

The second is the organizational and methodological subsystem: organization of the monitoring system in case of emergency, information about the state of the environmental components during the field or laboratory research. The practical part can be conducted using the research objects in research institutes, in the workplace and so on.

The third is the analytical and predictive subsystem: analysis, evaluation, predicting of possible emergencies, development of contingency plans and scenarios for their development, development of measures for timely detection of these situations, their prevention in order to ensure environmental safety.

The following methodological components of the workshop have been distinguished [10]:

- formulation of the topic and determination of its duration, taking into account theoretical and practical part;

workshop

- goal and task setting;

- identification of the objects and subjects of the workshop;

- determination of the venue for each part of the

- substantive content of the workshop, definition of forms, methods and means of training;

- individual tasks, formed for each participant of the workshop on the topic;

- selection of technical resources for the workshop;

-invitation of employers (stakeholders) in the field of environmental safety and protection of the population from emergencies, who are directly involved in the process of professional training.

\section{Results and discussion}

In the system of training of technogenic and ecological safety specialists, the methodology of training has been improved, namely, the workshop on "Emergency Monitoring" has been developed. It combines theoretical, practical and independent training. The purpose of the workshop is to create an emergency monitoring system on the example of a particular object and to develop possible scenarios for preventing and eliminating the consequences of an accident. 
To fulfill organizational and managerial as well as analytical and predictive tasks, the students used previously acquired knowledge and skills in environmental monitoring and safety. Under realistic conditions, the future experts considered possible scenarios for the emergence of dangerous situations in the territory of a certain region, created the system of crisis monitoring of the environmental components, developed practical recommendations on the ways of eliminating the accident and its prevention in the future. The results were based on students' surveys, consultations from university teachers and civil service professionals on emergency situations, environmental control and management.

Workshop on "Emergency Monitoring"

Number of hours: theoretical training -2 hours, practical training -6 hours.

Objective: to develop theoretical knowledge of the principles of organization of monitoring dangerous situations, basic methods and devices for its implementation, as well as to acquire practical skills for creation of a system of monitoring dangerous situations on the example of a certain object.

Objects: environmental objects, potentially dangerous objects.

Subjects: students of specialty 183 "Environmental Technologies", Master's degree, scientific and pedagogical staff.

Venue: higher education institution, State Emergency Service, potentially hazardous enterprises, State Environmental Inspection.

Information and theoretical training: "Basic concepts of operational monitoring", "Features of organizing and conducting operational monitoring", "Assessment of the state of emergency prevention at the enterprise".

Theoretical training is conducted in the form of training, debates and discussions, during which the students reveal: the basic concepts of operational environmental monitoring, regional or local environmental problems that can pose a potential risk to people and significantly pollute the environment, enterprises that are potentially dangerous and dangerous objects.

Practical training: "Development of tan emergency monitoring system at the enterprise", "Creation of a regional system of operational monitoring of environmental components", "Assessment of the state of the environment in an emergency".

In the process of practical study, students together with the invited stakeholders (using their practical experience), discuss the main dangerous situations that may occur in the territory of the settlement. They develop the map of high risk areas in the territory of the settlement.

Holding a business game. Students are divided into groups of 4 people. The teacher gives each group a card with different dangerous situations. Students develop an operational environmental monitoring system and develop measures to prevent the emergencies.

With a map of environmental pollution, the students need to create the environmental monitoring system for the period of liquidation of the accident consequences. The methods, tools and instruments that will be used during the monitoring should be noted as well.

Upon completion, students exchange views on techniques for assessing the state of the environment in an emergency situation. Each group is asked to discuss the question "What indicators should be monitored in different emergency situations"? "How do potentially hazardous and risky businesses affect the environment of the area?" At the end of the game, the teacher justifies the main stages of conducting operational monitoring observations.

Individual task: creation of a system for monitoring a potentially dangerous object under different scenarios: events of dangerous developments, prevention of dangerous situations, elimination of the consequences of an emergency situation.

Technical resources: computers, multimedia equipment.

Stakeholders invited: scientists of research institutions, industrial health safety and environment engineers, heads and specialists of regional departments of ecology and natural resources, ecological inspection, specialists of state emergency service.

The result of the workshop is the formation of organizational and managerial, analytical and predicting, production and technological, project and environmental components of professional competence of future specialists in technogenic and environmental safety [11].

According to the results of the workshop on the topic "Emergency Monitoring", future technogenic and environmental safety specialists analyze the possible scenarios for the development of hazardous situations, the features of their monitoring. They develop the environmental measures for prevention and elimination of dangerous situations.

Application of the workshop in training specialists provides an opportunity to prepare them for response in case of emergencies in any real existing location. At the same time, any object, located in the territory of Ukraine, can be used as such locations. Such an opportunity is especially valuable if the teacher wants to train specialists, flexible enough and ready to work in responsible positions, at actually existing conditions.

In recent years, Ukraine has been striving to reduce the migration of workers abroad, making it possible by recruiting for high-paying specialist positions in such fields as science, technology, engineering and mathematics. It is innovative training method, such as the workshop, that can train specialists who would be ready to set up an emergency monitoring system for actively functioning domestic enterprises and other hazardous sites. It will stop the outflow of specialists from Ukraine in future.

Thus, training technogenic and ecological safety specialists using the workshop ensures the formation of students' professional and practical knowledge and skills and provides the conditions for exchange of experience in the process of creating a monitoring system. Invited stakeholders have the opportunity to select and train specialists, capable of performing organizational, managerial, analytical and predicting tasks, even under conditions of objects and locations, existing at functioning Ukrainian enterprises.

\section{Conclusions}

1. The main subsystems and methodological components of the workshop have been distinguished and characterized. They ensure its efficient development and 
practical introduction into the educational process during the professional training of technogenic and environmental safety specialists.

2. The methodology of the workshop on the example of the topic "Emergency Monitoring" has been created. It is aimed at the formation of analytical, forecasting, production and technological as well as environmental components of the professional competence of future experts in technogenic and environmental safety.

\section{References}

1. Subramanian D. V., Kelly P. Effects of introducing innovative teaching methods in engineering classes: A case study on classes in an Indian university // Computer Applications in Engineering Education. 2018. Vol. 27, Issue 1. P. 183-193. doi: http://doi.org/10.1002/cae.22067

2. Voitovska O., Tolochko S., Bordyug N. Lifelong Learning in Modern Strategies of Sustainable Development // Studia warmińskie. 2018. Issue 55. P. 343-352. doi: http://doi.org/10.31648/sw.3081

3. A Review of Innovative Teaching Methods / Sivarajah R. T., Curci N. E., Johnson E. M., Lam D. L., Lee J. T., Richardson M. L. // Academic Radiology. 2019. Vol. 26, Issue 1. P. 101-113. doi: http://doi.org/10.1016/j.acra.2018.03.025

4. Pearce J. Teaching Science by Encouraging Innovation in Appropriate Technologies for Sustainable Development. 2019. URL: https://hal.archives-ouvertes.fr/hal-02120521/

5. Pometun O., Pyrozhenko L. Interaktyvni tekhnolohii navchannia: Teoriia, dosvid: textbook. Kyiv: A.P.N., 2002. 136 p. 2016. $231 \mathrm{p}$.

6. Sorochan T. M., Skrypnyk M. I. Tekhnolohii profesiinoho rozvytku pedahohiv: metodychnyi poradnyk: textbook. Kyiv,

7. Skrypnyk M. I. Interaktyvni tekhnolohii v pisliadyplomnomu navchanni: handbook. Kyiv, 2013. 232 p.

8. Maikovska V., Yurko I. Workshop as a tool of practical-based education and as a methodological and technological mean of entrepreneurial competence formation // Youth \& market. 2019. Issue 2 (169). P. 116-122. doi: http://doi.org/10.24919/23084634.2019.162832

9. Pysareva O. «Workshop» kak novyi vyd effektyvnohoobuchenyia // Sovety professyonalnoho psykholoha. URL: https://pisareva.by/workshop-kak-novyj-vid-effektivnogo-obucheniya/

10. Bordiuh N. S. Teoretychni i metodychni osnovy pidhotovky fakhivtsiv pryrodookhoronnoi haluzi do ekolohichnoho monitorynhu u systemi pisliadyplomnoi osvity: thesis of doctor of pedagogical sciences. Kyiv, 2019. $472 \mathrm{p}$.

11. Bordiuh N. S. Strukturno-funktsionalna model formuvannia profesiinykh kompetentnostei iz monitorynhu dovkillia u fakhivtsiv ekolohichnoho spriamuvannia // Pedahohichni nauky. 2018. Vol. 1, Issue 82. P. 95-99.

Received date 29.01.2020

Accepted date 12.01.2020

Published date 25.05.2020

Natalia Bordiug, Doctor of Pedagogical Sciences, Associate Professor, Department of Environmental Safety and Natural Resources Management, Zhytomyr National Agroecological University, Staryi blvd., 7, Zhytomyr, Ukraine, 10008

E-mail: natali-21@ukr.net

Anastasiia Rashchenko, PhD, Department of Environmental Safety and Natural Resources Management, Zhytomyr National Agroecological University, Staryi blvd, 7, Zhytomyr, Ukraine, 10008

E-mail: a.rashchenko@gmail.com

Tetyana Les, Department of Foreign Languages, Zhytomyr National Agroecological University, Stariy blvd., 7, Zhytomyr, Ukraine, 10008

E-mail: tetyana.les@gmail.com 